\title{
IMPRESSION OF LIQUIDITY, LEVERAGE, AND INDEPENDENT COMMISSIONERS ON THE VALUE OF NATIONAL PRIVATE BANK GENERAL COMPANIES
}

\author{
Sochib1 \\ Noviansyah Rizal2 \\ ${ }^{12}$ Departement of Accounting, STIE Widya Gama Lumajang, Lumajang, 67352, Indonesia \\ E-mail address: sochib.ak@gmail.com
}

\section{A R T I C L E I N F O}

Date of entry:

11 January 2020

Revision Date:

20 February 2020

Date Received:

15 March 2020

JEL Code: F65, G21, G32

\begin{abstract}
A B S T R A C T
Management hopes to make a profit with the intention of adding value to the company. Through the provision of sufficient bank funds to meet liquidity and lending to increase profitability and increasing company value. Company value is built by managing good company assets so that profits are obtained. This information gives a signal to the stock market and is responded by the market at stock prices. This study aims to determine the influence of liquidity, leverage, and independent commissioners on firm value. The study population is national private commercial banks listed on the Indonesia Stock Exchange in the 2014-2018 period. Samples were taken based on purpose sampling so that 17 samples were obtained. The study uses a linear regression approach with liquidity variables measured by Loan to Deposit Ratio, Leverage is measured by Debt to Equity Ratio, independent commissioners are measured by the number of independent commissioners, and company value is measured by Tobin's $Q$. The results that liquidity has a significant negative influence on the value of the company, leverage has no influence on the value of the company, and Independent Commissioners have a significant positive influence on the value of the company.
\end{abstract}

Keywords: Liquidity, Leverage, Independent Commissioner, Value

Cite this as: Sochib, S., \& Rizal, N. (2020). IMPRESSION OF LIQUIDITY, LEVERAGE, AND INDEPENDENT COMMISSIONERS ON THE VALUE OF NATIONAL PRIVATE BANK GENERAL COMPANIES. International Journal of Accounting and Management Research, 1(1), 21-29. https://doi.org/10.30741/10.30741/ijamr.vol1isss1

\section{INTRODUCTION}

The purpose of management in the operations strategy, in general, is to increase profitability. Management runs the company's operations have an obligation to achieve profit targets every period. Profit becomes a full part to cover the operational expenses incurred by the company and the desired profit of the company. The purpose of making a profit is needed for shareholder welfare. The achievement of company profits will provide information to the stock market as a signal to investors or company owners. Profit as expected performance of investors is the financial performance during the period. With financial performance, it can be seen the progress achieved by management in carrying out financial activities. Does management run it efficiently and effectively? In these circumstances, profit is needed to measure the measurement of its success. Company performance is a manifestation of management performance so that earnings can also be 
interpreted as a measurement of the effectiveness and efficiency of management to manage the resources entrusted to him (Suwardjono, 2005). As investors also want management to pay attention to the importance of efforts to provide incentives to the management team. The owner will encourage managers to want to work harder by using intensive range to maximize company value. The consideration is that the welfare of the owner also has an impact on increasing the value of the company (Sri Sulistyanto, 2008).

Management seeks to increase the company value, which will encourage welfare for shareholders. To assess the operational success and implementation of functions carried out by management that is by looking at the company value. Maximizing value company, in general, maximizes the stock price, because the value of the company is the price shares (Husnan, 1987). Research on company value has been carried out by previous researchers, such as, (Lumoly, Murni, \& Untu, 2018), (Antoro \& Hermuningsih, 2017), the results of the study concluded that liquidity had no effect on value company. But research (Dj, Artini, \& Suarjaya, 2012), concluded that liquidity has a significant effect on the observed firm value, liquidity is positively related and not significant (Lubis, Sinaga, \& Sasongko, 2017). Whereas the leverage variable of several studies conducted, such as (Hasibuan, Dzulkirom AR, \& Wi Endang NP, 2016), concluded that leverage, as measured by Debt to Equity Ratio, the effect is significant on the firm value variable (Tobin's Q). (Sambora, 2014) states leverage has no significant influence on company value. This research fits other researchers, such as (Ogolmagai, 2011), which gives the conclusion that the variable Debt to Equity Ratio has no significant influence on value company. Leverage is a comparison of how much funding needs are provided by creditors by comparing all liabilities to the company's total assets. Investors will assess the position of firm obligations to consider the decision that will be made.

The independent commissioner variable was also researched by (Azzahrah \& Willy, 2014) (Wibowo, 2015); (Nurfaza, 2017), which concluded that the independent commissioner did not affect the value of the company. Other researchers conclude that independent commissioners have a positive effect on firm value (Sochib, 2018b). The results of research on the variables of liquidity, leverage, and independent commissioners associated with the company value are still inconsistent. In this condition, researchers are encouraged to re-study the variables that affect firm value. Many other factors can affect a company's value, but in this study, the research problem was formulated, namely, What are the factors that can affect the company's value? Research questions on the formulation company's value problem, whether liquidity, leverage, and independent commissioners, can influence the value of a firm? Because of the research questions, the purpose of the study is to provide empirical evidence on how liquidity, leverage, Independent commissioners can influence the value of a company in national private commercial banks. The results of this empirical research discussion can provide benefits on strengthening the theory, especially studies of corporate value. It is also hoped that these findings can provide benefits and input to company management in an effort to understand the value of the entity because the goal of company management is to encourage company value so that management can strengthen its performance with factors supporting the value company.

The value company is a concern of management to be realized so that the level of shareholder welfare is met. The company will strive to maximize the prosperity of shareholders by taking action to increase the present value per share outstanding in the company (Sjahrial, 2014). The company's value is a picture of the firm profits that are responded to by the capital market. Management targets in each period try to achieve the agreed profit in the management team. When the company earns sufficient profits, the capital market will continue in the form of investor demand for these shares. This is where the supply and demand forces of the stock occur so that the stock price is formed with the company's earnings information. Efforts to add value to the company become the agenda of the management team with the hope that company value will be responded to by the share price so as to encourage the prosperity of the company owner. Companies that make profits, retained earnings will increase, and the book value of equity will increase. 
Increasing the book value of equity becomes part of the book value of an existing company, followed by an increase in its share price (Dedhy Sulistiawan, Yeni Januarsi, 2011). Liquidity is a necessity for companies to provide liquid equipment for the purpose of meeting obligations at all times. This ability to pay is maintained at all times so that the firm is able to fulfill its obligations. For banking companies, the ability to pay can be the ability to pay for operations, the ability to pay to customers who withdraw funds and pay to debtors who withdraw their credit facilities. The ability to pay for a company can be seen by Debt to Equity Ratio (DER). Balancing obligations with company equity forms a financial or financial structure. Management will consider the interests of the owner to improve welfare. Managers will choose a capital structure that maximizes the prosperity of shareholders (Sjahrial, 2014). In connection with the financial structure that the guidelines or rules of the vertical conservative financial structure provide a balance that must be maintained by the company regarding the amount of foreign capital with its own capital. A healthy expenditure budget must first be built on equity so that the structure of the financial structure determines the amount of loan capital under any condition should not exceed its own capital

Liquidity for banks has a role in managing the performance of management, which includes operational withdrawals of funds by depositors and debtors as well as corporate operational obligations or other obligations that are due. A measure that can be used to calculate bank liquidity is a Loan to Deposit Ratio (LDR) determined in accordance with BI Regulation Number 15/15 / PBI / 2013. In general, it can be said that the bank is liquid if the bank management is able to pay all short-term obligations at any time to the depositor, and is able to meet all the disbursement of the credit facilities that must be met, and all operational costs. Research conducted (Rompas, 2013) concludes that liquidity on firm value influences. Liquidity on firm value has a significant positive effect (A. N. D. A. Putra \& Lestari, 2019). $\mathrm{H}_{1}$. There is an influence of liquidity on firm value. Leverage can be an estimate of how much debt to use. Measurements can use a loan to deposit ratio (LDR). LDR is a ratio that is used to see the company's liquidity. This ratio measures the composition of the number of loans extended compared to the number of third party funds raised by banks. Loan to Deposit Ratio indicates the ability of banks when there is a withdrawal of funds by depositors or the realization of loans.

Loan to Deposit Ratio is the bank's management strategy; conservative bank management prefers a low loan to deposit ratio. Otherwise, if the LDR exceeds regulatory requirements, it is said that bank management is very expansive/aggressive. The high ratio gives an indication of the lower ability of the bank's liquidity concerned, due to the greater amount of funds needed to finance loans. This ratio is also an indicator ability of a bank. The tolerance limit for a bank's LDR is around $80 \%$, with a tolerance range of $85 \%$. The leverage variable, which is proxy by DER, has a significant effect on the variable firm value (Hasibuan et al., 2016). $\mathrm{H}_{2}$. There is a leverage effect on firm value. Independent Commissioners are part of the Board of Commissioners who are not from outside parties who are not affiliated. Independent Commissioners are at least $30 \%$ of the total number of commissioners registered at the company (OJK, 2015). Independent Commissioners in this study were measured using a ratio between the number of independent commissioners to the number of boards of commissioners. A supervisory system in an integrated company requires the existence of a proactive, independent commissioner. Independent commissioners have the task of controlling management to account for all activities carried out transparently and in accountability. A good supervision and control system will prevent managers from hiding, changing, or delaying information that should be known by the public (Sri Sulistyanto, 2008). Research conducted on an independent commissioner concluded the value of the company affected by the independent commissioner (Sochib, 2018b). $\mathrm{H}_{3}$. There is an influence of independent commissioners on firm value. 


\section{METHODS}

This study uses data financial statements of audit banking companies listed on the Indonesia Stock Exchange in 2014-2018. The population is the national private commercial bank company that has been listed on the Indonesia Stock Exchange (IDX), which was observed during the period 2014-2018. This study uses the purposive sampling method to obtain a representative sample with certain requirements criteria. Data collection is carried out by identifying and analyzing the annual audit financial report (audit report) obtained through the Indonesia Stock Exchange on the website wwwidx.co.id. Variables in this study include independent variables consisting of liquidity, leverage, independent commissioners, and the dependent variable, namely the value of the company. The liquidity variables use Loan to Deposit Ratio (LDR) measurements; the leverage variables use Debt to Equity Ratio (DER) measurements, the independent commissioner variables use the proportion of independent commissioners measurement, and company value is using Tobin's $Q$ measurements. Research the effect of independent variables on the dependent variable observed using linear regression techniques.

\section{RESULTS AND DISCUSSION}

The object of this research is a national private commercial bank company listed on the Indonesia Stock Exchange with an observation period of 2014-2018. The population in this study was 43 national private commercial banks after identification with the purpose sampling method; a sample of 17 entities was obtained. Criteria for sampling include Private commercial banks nationally listed on the Indonesia Stock Exchange, which published audited annual financial statements in the 2014-2018 period. Having the data needed in the research are liquidity, leverage, independent commissioners, and company value. Issuers always make profits every year with observations made for five years starting in the period 2014-2018 so as to obtain 85 observations. Descriptive statistical results in this study provide an overview of the research data analyzed. Important information obtained that the number of observations in this study amounted to 85 times the observations. Other information regarding the description of research data is minimum, maximum, mean, and standard deviation values. Descriptive statistics that provide an overview of data seen from the mean, standard deviation, variance, maximum, minimum, sum, range, kurtosis, and skewness (Ghozali, 2016). This study uses independent variables, namely liquidity, leverage, independent commissioners, and the firm's dependent variable.

Table 1. Descriptive statistics

\begin{tabular}{lrrrrr}
\hline & N & Minimum & Maximum & Mean & Std. Deviation \\
\hline Likuiditas & 85 & 0,42 & 0,99 & 0,7201 & 0,11341 \\
Leverage & 85 & 2,83 & 14,80 & 5,5431 & 2,06215 \\
Komisaris Independen & 85 & 0,00 & 0,75 & 0,5382 & 0,16587 \\
Nilai Perusahaan & 85 & 0,74 & 1,59 & 1,0206 & 0,18930 \\
\hline
\end{tabular}

The results of statistical processing in table 1 obtained information that the liquidity variable which is the ratio of Credit Provided to Third Party Funds and Capital has a minimum and maximum value of 0.42 and 0.99 of total third party funds and capital with a mean value of 0,72 in five years and a standard deviation of 0.11 . The leverage variable that shows the composition of debt has a minimum value of 2.83 and a maximum value of 14.80 of total equity with a mean value of 5.54 in five years and a standard deviation of 2.062. The independent commissioner variable, which shows the proportion of the number of independent commissioners, has a minimum value of 0.00 and value a maximum of 0.75 of the total number of boards with a mean value of 0.53 and a standard deviation of 0.16 . While the company value variable, which shows the total Market Value and a total book value of liabilities to total assets, is 0.74 and a 
maximum of 1.59 in five years, and the mean and standard deviations are 1.02 and 0.189 , respectively.

With statistical testing, information is obtained: first, the Kolmogorov Smirnov test, which shows a p-value of $0.18>0.05$ so that the assumption of residual normality or normality of residuals is fulfilled. Both of the Durbin Watson values are 2,029 with a du value of 1.7210 and a 4-du value of 2,279 so that the criteria for $\mathrm{du}<\mathrm{d}<4-\mathrm{du}$ are met. With these results, it means that there is no positive or negative autocorrelation in the research data. Third, the value of the Variant Inflated Factor (VIF) of independent variables (liquidity, leverage, and independent commissioners) in this study has a VIF value $<10$. It can be concluded that multicollinearity between independent variables is no problem. Fourth, the results of scatterplot showed that the research data spread randomly not to form certain patterns. This means there is no problem of heteroscedasticity or homoscedasticity of residuals on residuals. Thus the data of this study meet the classical assumption test criteria. Furthermore, testing the research model with the F test is a test to assess how well the research model is used. The results of statistical processing obtained the value of each independent variable with a different level of significance listed in table 2.

Table 2. Coefficients

\begin{tabular}{lccccc}
\hline \multirow{2}{*}{ Model } & \multicolumn{2}{c}{$\begin{array}{c}\text { Unstandardized } \\
\text { Coefficients }\end{array}$} & $\begin{array}{c}\text { Standardized } \\
\text { Coefficients }\end{array}$ & t & Sig. \\
\cline { 2 - 4 } & B & $\begin{array}{c}\text { Std. } \\
\text { Error }\end{array}$ & Beta & & \\
\hline (Constant) & 1,251 & 0,131 & & 9,573 & 0,000 \\
Likuiditas & $-0,702$ & 0,159 & $-0,420$ & $-4,401$ & 0,000 \\
Leverage & 0,014 & 0,009 & 0,153 & 1,603 & 0,113 \\
Komisaris Independen & 0,366 & 0,107 & 0,321 & 3,415 & 0,001 \\
\hline
\end{tabular}

Based on table 2, the results of statistical processing obtained an $\mathrm{F}$ test with a significance value of $0,000<0.05$ with an $R$ Square value of 0.290 . This means that the research model with liquidity, leverage, and independent commissioner variables as independent variables jointly influences the value of the company by $29 \%$. Likewise, the testing of each independent variable is partially carried out through the $\mathrm{t}$ or $\mathrm{t}$-test. The liquidity variable to show a significance value of $0.00<0.05$ means the liquidity variable has a significant influence on the firm's value. The hypothesis which states that there is an influence of liquidity on firm value is acceptable. The leverage variable gets a significance value of $0.11>0.05$, which means the leverage variable is not significant. The hypothesis that leverage has an effect on firm value is rejected. While the independent commissioner variable obtained a significance value of $0.00<0.05$, which means the independent commissioner variable had a significant influence on the firm's value. The hypothesis that independent commissioners influence the value of the company is accepted. With these statistical results, the regression equation model in this study can be formulated $\mathrm{Y}=1.251-0.702 \mathrm{X}_{1}+0.014 \mathrm{X}_{2}+0.366 \mathrm{X}_{3}$.

Liquidity in this study uses a Loan to Deposit Ratio (LDR) proxy or the level of lending to debtors funded by Third Party Funds and the own company capital. Based on the results of the analysis of the influence of liquidity, which is proxied Loan to Deposit Ratio (LDR) on the value of the company shows a negative and significant effect, as in table 2 . The results of this study mean that when lending or Loan to Deposit Ratio (LDR) is low, then the value of the company rises, and when lending or high LDR, the company value decreases. According to Bank Indonesia, the lowest bank must channel funds to lending by $78 \%$ and a maximum of $92 \%$ from third-party funds and own capital. On the other hand, the LDR is an indicator of the ability of banks to provide sufficient liquid funds for customer withdrawals. The ability to provide funds or liquidity is a bank obligation that includes obligations for day-to-day operations, the obligation to provide liquidity for withdrawals of funds by depositors, both savings, current accounts, and withdrawal of 
deposits and disbursement of credit facilities on the realization of loans approved by bank management. With LDR, it means that the bank has extended credit to the debtor with funds owned and the bank will get a reward in the form of loan interest. This loan interest becomes the main income of banking operations and will form the company's profit. But LDR is also an indicator of the ability of banks to provide sufficient liquid funds whenever there is a withdrawal from customers. This study proves that LDR has a significant negative effect on firm value. Of the 85 observations of LDR, there were 58 observations of LDR or $68 \%$ are in a position below the lowest LDR level according to Bank Indonesia regulations with an average company value of 1.05. In the low LDR position, the price of shares on the stock exchange closed with the stock price rising. Investors have confidence that with a relatively low LDR, the company still has enough margin to cover operating expenses, and the company has sufficient ability to maintain liquidity.

As a banking entity, the liquidity is a guideline for investors to make decisions about the company whether investors want to invest in the company because banking is an intermediary institution that gives confidence to depositors to remain loyal to put their funds in the bank. A total of 23 LDR observations or $27 \%$ with a position in accordance with Bank Indonesia regulations, namely between $78 \%-92 \%$ with an average value of the company of 0.96 . A total of 4 LDR observations or $5 \%$ with an LDR position above Bank Indonesia regulations with an average company value of 0.86 . In this position, the company is in the category of violation of LDR provisions so that it is likely that the ability to provide sufficient liquid funds will be volatile. The market also responded negatively so that stock prices closed with prices falling, and the value of the company also declined. There is a tendency with a relatively low LDR or sufficient liquidity supply, which sufficiently pushes the closing stock price on the stock exchange to rise and pushes the value of the company to increase. The findings of this study differ from other studies which state that liquidity has a significant positive effect on firm value (Y. D. Putra \& Wiagustini, 2013). Liquidity has no significant effect on firm value (Antoro \& Hermuningsih, 2017), whereas LDR is positively and not significantly related to PBV (Lubis et al., 2017). Liquidity (LDR) has a negative and not significant effect on firm value (Antoro \& Hermuningsih, 2017). Liquidity does not have a significant effect on Company Value (Lumoly et al., 2018).

Leverage in this study uses a proxy for Debt to Equity Ratio (DER) or the company's capital structure (Sjahrial, 2014). The use of debt in a company's capital structure is called financial leverage (Ross \& Westerfield, 2015). Based on the results of the analysis of the influence of leverage, proxied Debt to Equity Ratio (DER) to the value of the company shows a positive but not significant effect, as in table 2 . The results of this study have any meaning DER or leverage formed in the capital structure mix; the company's value is not affected. According to (Ross \& Westerfield, 2015), financial leverage will increase potential returns for shareholders, but financial leverage also has the potential to increase financial difficulties and corporate failures. The company expects an optimal capital structure that does not add to the burden borne by the company. Descriptive analysis results during the period 2014-2018 showed the average leverage has decreased growth. The leverage position in 2014 averaged 6.32 down to 4.88 in 2018 . This means that in the banking sector, there was a decrease in third-party fund collection, and the use of debt in the capital structure of the sample companies meant that leverage increased. Meanwhile, the value of the company measured by Tobin's $Q$ stagnated with an average of 2014 of 1.03 to 2018 of 1.01 . Based on the relationship between increased leverage growth in the banking sector with insignificant company value, descriptively, there is a non-positive positive close relationship.

The results of this study are supported by other studies that state that leverage (DAR) has no significant effect on firm value (Antoro and Hermuningsih 2017). Leverage (DAR) has no effect on the value of the company that is proxy for Price to Book Value (Sambora 2014), and other research states that leverage (DAR) has no significant effect on the firm value measured by Tobin's Q (Ogolmagai 2011). Other researchers stated that DER was negatively and not significantly related to Price to Book Value (Lubis, Sinaga, and Sasongko 2017) whereas different research states that leverage has a significant positive 
effect on firm value (Y. D. Putra and Wiagustini 2013). Leverage does not have a significant negative effect on firm value ( $\mathrm{Dj}$, Artini, and Suarjaya 2012). The independent commissioner in this study uses a proxy for the proportion of the number of independent commissioners to the number of the board of commissioners. Based on the results of the analysis shown in table 2, it can be proven that the proportion of independent directors has a significant positive effect on company value. The results of the study mean that the proportion of independent commissioners formed affects the value of the company. Independent commissioners have the duty to oversee management in operations. According to the Financial Services Authority Regulation (OJK), the proportion of independent commissioners is at least $30 \%$ of the total number of Commissioners. In the event that the Board of Commissioners consists of more than 2 (two) members of the Board of Commissioners, the number of Independent Commissioners must be at least $30 \%$ (thirty percent) of the total members of the Board of Commissioners (OJK, 2014).

The results of the descriptive analysis of independent commissioners during the period 2014-2018 showed an average of $93 \%$ or as many as 79 sample entities, the proportion of independent commissioners above the OJK provisions above 30\%. Thus the supervisory function performed by an independent commissioner is carried out effectively. Management will carry out effective business strategies, guaranteed transparency, and disclosure of the company's financial statements. In accordance with the mission of the independent commissioner in empowering management resources to run a healthy and responsible business. Responsible for encouraging the application of the principle of Good Corporate Governance through empowering the board of commissioners so that they can carry out supervisory duties and provide advice to managers effectively and provide added value to the company (Sri Sulistyanto, 2008). The results of this study were supported by several researchers who found the independent commissioner to have a significant and significant effect on company value (Purbopangestu 2014), (Fajar 2018), (Sochib 2018a). In contrast to research, which states that independent commissioners have no effect on company value (Azzahrah and Willy 2014). Independent Commissioner has no significant effect on Company Value (Wibowo 2015), (Nurfaza 2017).

\section{CONCLUSION}

This study examines issues of liquidity, leverage, independent commissioners, and company value at the national private commercial banks in the 2014-2018 period. Based on data analysis and discussion produces a conclusion. The results showed that the liquidity, which has a proxy for Loan to Deposit Ratio (LDR), has a significant influence on the negative direction on firm value. This liquidity can be seen from the point of view of the bank's ability to extend credit for the funds it collects so as to make a profit. Liquidity can also be seen as the ability of banks to provide sufficient liquidity for withdrawals of depositors, loan disbursements approved by management and internal operations. Because banks have an intermediation function, liquidity has a significant influence on the negative direction on firm value. Leverage proxied by Debt to Equity Ratio (DER) has no significant effect on company value. This leverage is how much bank obligations must be supported by the assets owned. As an intermediary institution, the bank has a function to collect from the customer as a source of funds. Whatever the amount of public funds that can be collected by banks does not mean company value will rise. The value will depend on public trust in the bank as an institution of trust in the funds deposited in the bank.

Independent commissioners proxy. The proportion of Independent Commissioners has a significant positive effect on company value. Independent commissioners are indeed tasked with overseeing the implementation of management operations and providing advice to management. Independent commissioners who are active with the role played, management will be driven to run the company with transparency, high accountability. Investors who put their hopes in the performance of independent commissioners will respond with a desire to continue investing in the company. For academics that the results of this study are expected to provide input on the development of the field of 
financial management. Knowledge information about the value of the company and the factors that can predict it. For management, the results of this study can be used as input factors that can increase the company value. For investors, the findings in this study can be used in management decisions. This study has limitations, especially in the sampling, which is still limited to national private commercial banks, and only to the variables of liquidity, leverage, and independent commissioners. Therefore in this research model, the value of $\mathrm{R}$ Square is $29 \%$, so that many other factors can be included to predict the value of the company.

\section{REFERENCES}

Antoro, A. D., \& Hermuningsih, S. (2017). Kebijakan Dividen Dan Bi Rate Sebagai Pemoderasi Likuiditas, Profitabilitas, Dan Leverage Terhadap Nilai Perusahaan Perbankan Yang Terdaftar Di BEI Tahun 2011-2017. Upajiwa Dewantara, 2(1), 5875.

Azzahrah, Z., \& Willy, S. Y. (2014). Pengaruh Mekanisme Good Corporate Governance Terhadap Nilai Perusahaan (Studi Pada Sektor Perbankan yang Terdaftar di Bursa Efek Indonesia tahun 2009-2013). E-Proceeding of Management: Vol.1, No.3 Desember 2014 | Page 203, ISSN : 2355-9357, 1(3), 203-213.

Sulistiawan, D., Januarsi, Y. L. A. (2011). Creative Accounting Mengungkap Manajemen Laba dan Skandal Akuntansi (1st ed.). Jakarta: Salemba Empat.

Dj, A. M., Artini, L. G. S., \& Suarjaya, A. . G. (2012). Pengaruh Kinerja Keuangan terhadap Nilai Perusahaan dengan Kebijakan Dividen sebagai Variabel Pemoderasi. Jurnal Manajemen, Strategi Bisnis, Dan Kewirausahaan, 6(2), 130-138. https://doi.org/10.1017/CBO9781107415324.004

Fajar, N. (2018). Pengaruh Ukuran Komite Audit, Ukuran Dewan Direksi Dan Komisaris Independen Terhadap Nilai Perusahaan.

Ghozali, I. (2016). Aplikasi Analisis Multivariete dengan Program IBM SPSS 23 (8th ed.). Semarang: Badan Penerbit Universitas Diponegoro.

Hasibuan, V., Dzulkirom AR, M., \& Wi Endang NP, N. (2016). PENGARUH LEVERAGE DAN PROFITABILITAS TERHADAP NILAI PERUSAHAAN (Studi pada Perusahaan Property dan Real Estate yang Terdaftar di Bursa Efek Indonesia Periode Tahun 2012-2015). Jurnal Administrasi Bisnis S1 Universitas Brawijaya, 39(1), 139-147.

Husnan, S. (1987). Manajemen Keuangan, Teori dan Penerapan. Yogyakarta: BPFE Yogyakarta.

Lubis, I. L., Sinaga, B. M., \& Sasongko, H. (2017). Pengaruh Profitabilitas, Sruktur Modal, Dan Likuiditas Terhadap Nilai Perusahaan. Jurnal Aplikasi Bisnis Dan Manajemen, 3(3), 458-465. https://doi.org/10.17358/jabm.3.3.458

Lumoly, S., Murni, S., \& Untu, V. N. (2018). Pengaruh Likuiditas, Ukuran Perusahaan dan Profitabilitas Terhadap Nilai Perusahaan (Studi Pada Perusahaan Logam Dan Sejenisnya Yang Terdaftar di Bursa Efek Indonesia). Jurnal EMBA, 6(3), 1108-1117.

Nurfaza, G. dan I. (2017). Pengaruh Good Corporate Governance Terhadap Nilai Perusahaan ( Studi Pada Sektor Perbankan yang Terdaftar di Bursa Efek Indonesia ( BEI ) Tahun 2011-2015 ) EFFECT OF GOOD CORPORATE GOVERNANCE TO CORPORATE VALUES ( Studies in Banking Sector Listed in Indon. E-Proceeding of Management :, 4(3), 2261-2266.

Ogolmagai, N. (2011). Leverage Pengaruhnya Terhadap Nilai Perusahaan Pada Industri Manufaktur Yang Go Public Di Indonesia. Journal EMBA, 1(3), 81-89.

OJK. (2014). Otoritas jasa keuangan republik indonesia. OJK.

OJK. (2015). Penerapan Tata Kelola Bagi Bank Umum. Ojk.Go.Id, 1-29. Retrieved from http://www.ojk.go.id/id/kanal/iknb/regulasi/lembaga-keuanganmikro/peraturan-ojk/Documents/SAL-POJK PERIZINAN FINAL F.pdf

Purbopangestu, H. W. (2014). Pengaruh Good Corporate Governance Terhadap Nilai Perusahaan Dengan Corporate Social Responsibility Sebagai Variabel Intervening. Accounting Analysis Journal, 321-333. https://doi.org/10.15294/aaj.v3i3.4202

Putra, A. N. D. A., \& Lestari, P. V. (2019). Pengaruh Profitabilitas, Likuiditas, Dan Ukuran Perusahaan Terhadap Nilai Perusahaan Melalui Kebijakan Dividen. E-Jurnal 
$\begin{array}{lll}\text { Manajemen Universitas } \quad \text { Udayana, } & 8(5),\end{array}$ https://doi.org/ 10.24843/ ejmunud.2019.v08.i05.p25

Putra, Y. D., \& Wiagustini, N. L. P. (2013). Pengaruh Likuiditas Dan Leverage Terhadap Profitabilitas Dan Nilai Perusahaan Pada Perusahaan Perbankan Di Bei. Jurnal Wawasan Manajemen, 1(2), 215-232. https://doi.org/10.1145/291080.291123

Rompas, G. P. (2013). Likuiditas, Solvabilitas dan Rentabilitas Terhadap Nilai Perusahaan BUMN Yang Terdaftar Di BEI. Jurnal EMBA, 1(3), 252-262.

Ross, S. A., \& Westerfield, R. W. (2015). Pengantar Keuangan Perusahaan (Global Asi; C. Sasongko, ed.). Jakarta: Salemba Empat.

Sambora, M. (2014). PENGARUH LEVERAGE DAN PROFITABILITAS TERHADAP NILAI PERUSAHAAN (Studi pada Perusahaan Food and Beverages yang terdaftar di BEI periode tahun 2009 â 2012). Jurnal Administrasi Bisnis, 8(2).

Sjahrial, D. (2014). MAnajemen Keuangan Lanjutan (Edisi Revi). Jakarta: Mitra Wacana Media.

Sochib. (2018a). Mekanisme Fungsi Manajemen Keuangan Dan Nilai Perusahaan. AssetsWidya Gama Lumajang, 2(1), 1-7. Retrieved from http://ejournal.stiewidyagamalumajang.ac.id/index.php/ asset\%OAMekanisme

Sochib. (2018b). Pengaruh Manajemen Laba Pada Nilai Perusahaan Dengan Komisaris Independen Sebagai Variabel Intervening. Proceedings, 1(1), 360-371.

Sri Sulistyanto. (2008). Manajemen Laba: Teori dan Model Empiris (1st ed.). Jakarta: Grasindo.

Suwardjono. (2005). Teori Akuntansi (1st ed.). Jogyakarta: Badan Penerbit Fakultas Ekonomi Jogyakarta.

Wibowo, S. (2015). Pengaruh Komisaris Independen, Komiter Audit, Dewan Komisaris, Kempemilikan Manajerial dan Dewan Direksi Terhadap Nilai Perusahaan. 84-102. 